\title{
Increasing the occupational health and safety level by using specialized software
}

\author{
Marius Simion Morar ${ }^{*}$,Vlad Mihai Păsculescu, Cristian Raul Cioară, and Andrada Denisa \\ Băbuţ
}

National Institute for Research and Development in Mine Safety and Protection to Explosion INSEMEX, 32-34 G-ral Vasile Milea street, 332047, Petrosani, Hunedoara county, Romania

\begin{abstract}
Worldwide, but also at European Union level, the mining industry is subject to legislative and technical restrictions. For mining coal from underground is used a complex network of horizontal, vertical and inclined mine workings aiming at transporting and exhausting coal at the surface. In every mine unit, very important is the ventilation network, used for ensuring the oxygen for workers, for diluting explosive and/or toxic gases and for exhausting heat and humidity form the underground. Coal mining involves the risk of spontaneous combustion which, besides methane accumulations and improper ventilation, represents the main source generating work accidents, sometimes resulting in human losses. The current article proposes an analysis of the potentially explosive and/or toxic atmosphere for a longwall with undermined coal bed and of the use of specialized software for increasing the underground safety level by mining ventilation improvement.
\end{abstract}

\section{Introduction}

The present paper aims to analyse the possibility of increasing the occupational health and safety level underground, as well as to perform an analysis of the potentially explosive and / or toxic atmosphere within a longwall with undermined coal bed.

The analysis is performed over a previous ventilation situation from the Uricani mining unit, namely on the longwall with undermined coal bed located in panel 5 , layer 3 , block IV.

For increasing the OHS level within the longwall with undermined coal bed was used the specialized software 3D CANVENT.

\section{Generalities}

Following the analysis of the existing documentation from the research studies carried out before, the way of preparing and exploiting the longwall with undermined coal bed panel 5, layer 3, block IV, the following have been noticed:

\footnotetext{
* Corresponding author: marius.morar@insemex.ro
} 
- The long wall with undermined coal bed is opened by mining preparatory works executed at two different levels as follows:

- $\quad$ at the upper level there is an inclined access plane layer 3, the upper base gallery, the transversal research gallery layer 3 and the upper head gallery layer 3;

- $\quad$ at lower level there is an inclined base plan, a lower base gallery, longwall with undermined coal bed, the lower head gallery layer 3 and the transversal research gallery no. 3;

- the upper base gallery layer 3, in horizontal plane, is inside an exploitation area, respectively it crosses the lower base gallery on a length of $24 \mathrm{~m}$, from the intersection area with the access gallery to the rising which connects with the research area from layer 5;

- the upper base gallery layer 3 is located horizontally outside the exploitation area on a length of about $63 \mathrm{~m}$;

- the upper head gallery is entirely within the operating area.

In order to carry out the coal exploitation in safety conditions within the longwall with undermined coal bed, the environmental conditions have been monitored for a fixed period of 30 days.

In order to monitor the workplace atmosphere, namely the aerodynamic parameters, samples were collected for analysis [1,2].

In order to determine the atmosphere of the workplace and to track the phenomenon of self-heating, fire indices were determined [3].

In Romania, the fire indices used to track the phenomenon of self-heating are: Graham index $\mathrm{R}_{1}$, respiration index $\mathrm{R}_{2}$, ethylene $\mathrm{C}_{2} \mathrm{H}_{4}$ and acetylene $\mathrm{C}_{2} \mathrm{H}_{2}$.

\section{Interpretation of fire indices}

\subsection{Graham index (R1)}

The Graham index can take values greater than zero depending on the stage of the oxidation process (self-heating, self-ignition, fire) as follows [4], [5]:

- $\mathrm{R} 1<0,4-$ normal situations

- $\mathrm{R} 1 \geq 0,4$ - the beginning of the self-heating process, situation in which the application of preventive measures is required.

- $\mathrm{R} 1=2 \div 3$ - the lower limit of the self-ignition process, in which case the danger of fire is imminent.

- $\mathrm{R} 1 \longrightarrow 25$ - indicates the existence of an endogenous fire

- $\mathrm{R} 1 \longrightarrow 60$-indicates the existence of an exogenous fire

\subsection{Breath index (R2)}

This index is characterized by the following values:

- $\mathrm{R} 2<60$ - normal situations

- $\mathrm{R} 2 \geq 60$ - the beginning of the self-heating process

For ethylene: If the concentration of ethylene exceeds $0.0005 \%$, the oxidation process is considered to be initiated.

At values $\geq 0.001 \%$ the process reaches the self-heating phase and in the case of an endogenous fire it reaches values $\geq 0.006 \%$.

For acetylene: The concentration of acetylene in the self-ignition phase reaches values $\geq$ $0.0001 \%$. 
In order to characterize the phenomenon, these indices are taken into consideration, and the interpretation of the phenomenon takes into account the values that indicate the most dangerous situation.

In order to determine the ventilation parameters for the mining unit and from within the longwall, measurements regarding the air status parameters and the quantity of air that crosses the longwall are performed.

Following the measurements carried out underground resulted the situation presented in Table 1.

Table 1. Gas measurement results

\begin{tabular}{|c|c|c|c|c|c|c|c|c|c|}
\hline \multirow[b]{2}{*}{ Period } & \multirow{2}{*}{$\begin{array}{c}\text { Place of } \\
\text { Measurement }\end{array}$} & \multicolumn{6}{|c|}{ Gas concentrations (\%) } & \multirow{2}{*}{$\begin{array}{c}\text { Graham } \\
\text { index } \\
\mathbf{R}_{1}\end{array}$} & \multirow{2}{*}{$\begin{array}{c}\text { Breath } \\
\text { index } \\
\mathbf{R}_{2}\end{array}$} \\
\hline & & $\mathbf{O}_{2}$ & $\mathrm{CO}_{2}$ & $\mathrm{CH}_{4}$ & $\mathrm{CO}$ & $\mathrm{C}_{2} \mathrm{H}_{4}$ & $\mathrm{C}_{2} \mathrm{H}_{2}$ & & \\
\hline \multirow{5}{*}{$\begin{array}{l}\text { Week } \\
1\end{array}$} & Basic gallery & 20.6 & 0.02 & 0 & 0 & - & - & - & - \\
\hline & \multirow{3}{*}{ Strip slaughter } & 20.6 & 0.02 & 0 & 0 & - & - & - & - \\
\hline & & 20.6 & 0.02 & 0 & 0 & - & - & - & - \\
\hline & & 20.5 & 0.10 & 0.35 & 0 & - & - & - & 22.7 \\
\hline & Head gallery & 20.4 & 0.11 & 0.40 & 0 & - & - & - & 20.3 \\
\hline \multirow{7}{*}{$\begin{array}{c}\text { Week } \\
2\end{array}$} & Basic gallery & 20.6 & 0.05 & 0.20 & 0 & - & - & - & - \\
\hline & \multirow{5}{*}{ Strip slaughter } & 20.5 & 0.06 & 0.25 & 0 & - & - & - & - \\
\hline & & 20.5 & 0.06 & 0.25 & 0 & - & - & - & - \\
\hline & & 20.5 & 0.07 & 0.25 & 0 & - & - & - & - \\
\hline & & 20.4 & 0.10 & 0.20 & 0.0005 & - & - & 0.09 & - \\
\hline & & 20.3 & 0.10 & 0.80 & 0.0015 & - & - & 0.23 & 15.6 \\
\hline & Head gallery & 20.3 & 0.10 & 0.45 & 0.0002 & - & - & 0.03 & 15.6 \\
\hline \multirow{10}{*}{$\begin{array}{l}\text { Week } \\
3\end{array}$} & Basic gallery & 20.5 & 0.06 & 0.40 & 0 & - & - & - & 13.6 \\
\hline & \multirow{8}{*}{ Strip slaughter } & 20.5 & 0.07 & 0.40 & 0 & - & - & - & 15.9 \\
\hline & & 20.5 & 0.07 & 0.40 & 0 & - & - & - & 15.9 \\
\hline & & 20.5 & 0.07 & 0.40 & 0 & - & - & - & 15.9 \\
\hline & & 20.5 & 0.07 & 0.40 & 0 & - & - & - & 15.9 \\
\hline & & 20.4 & 0.08 & 0.50 & 0 & - & - & - & 14.8 \\
\hline & & 20.4 & 0.08 & 0.55 & 0 & - & - & - & 14.8 \\
\hline & & 19.9 & 0.25 & 2.5 & 0.0005 & - & - & 0.05 & 24.0 \\
\hline & & 20.4 & 0.04 & 0.50 & 0 & - & - & - & 14.8 \\
\hline & Head gallery & 20.2 & 0.15 & 1.20 & 0 & - & - & - & 20.3 \\
\hline \multirow{10}{*}{$\begin{array}{c}\text { Week } \\
4\end{array}$} & Basic gallery & 20.6 & 0.05 & 0.25 & 0 & - & - & - & - \\
\hline & \multirow{8}{*}{ Strip slaughter } & 20.6 & 0.08 & 0.40 & 0 & - & - & - & - \\
\hline & & 20.6 & 0.09 & 0.40 & 0 & - & - & - & - \\
\hline & & 20.6 & 0.09 & 0.40 & 0 & - & - & - & - \\
\hline & & 20.5 & 0.10 & 0.45 & 0 & - & - & - & 22.7 \\
\hline & & 20.6 & 0.10 & 0.40 & 0 & - & - & - & - \\
\hline & & 20.4 & 0.10 & 0.40 & 0 & - & - & - & 18.2 \\
\hline & & 20.5 & 0.10 & 0.40 & 0 & - & - & - & 22.7 \\
\hline & & 20.3 & 0.12 & 0.50 & 0 & - & - & - & 18.7 \\
\hline & Head Gallery & 20.3 & 0.15 & 0.60 & 0 & - & - & - & 23.4 \\
\hline
\end{tabular}




\subsection{Ventilation network solving for increasing the OHS level}

For optimizing the mining ventilation network was used the specialized software 3D CANVENT [6].

For providing the best solution available for such a complex ventilation network, there has been used the Hardy-Cross method for successive approximations.

This software supported the development of the solution for the ventilation network as well an optimization of the air flow distribution within the ventilation branches.

The settlement of the ventilation network related to Uricani mining unit involved several phases:

- Marking the junctions of the ventilation network on the spatial diagram of the mine;

- Determining the geodesic coordinates of the identified junctions;

- Inputting the geodesic coordinates of junctions and the existing branches into the database of the software;

- Carrying out of measurements on site; these measurements include:

$\circ$ measurements of the aerodynamic parameters of mine workings;

- measurements of the geometrical parameters of mine workings;

- measurements of the physical parameters of the air;

- Calculation of aerodynamic strength specific to each branch;

- Inputting the values of parameters specific to the ventilation network into the expert software;

- $2 \mathrm{D}$ or 3D drawing of the ventilation network;

- Balancing the ventilation network;

- Settling the ventilation network. Both the direction and the optimum distribution of the air flows along each branch are being identified in this stage;

- Generating the results.

This final stage provides the data on electronic support or paper regarding the graphic settlement of the ventilation network.

After analyzing the basic situation, for the Uricani mining unit the nodes and branches necessary for a good running of the program were introduced.

As a result of the computer simulation, it was found that for the optimization of the distribution of air flow at the level of the mining unit and within the longwall with undermined coal bed it is required to increase the dilution of the gases released within the longwall abatement, resulting in an increased safety level, being required to eliminate three ventilation constructions.

Once the ventilation constructions were removed, the software was run once again and it was found that the air flow and related conditions within the longwall with undermined coal bed were improved.

\subsection{Relevant discussions and results}

For optimizing the mining ventilation network was used the specialized software 3D CANVENT.

By using the 3D CANVENT program, the aim was to optimize the air flow, especially at the level of the longwall with undermined coal bed.

In order to use the 3D CANVENT program, in situ measurements were taken, taking the geodetic coordinates from the maps made available by the mining unit and introducing the nodes and branches into the program.

By running the 3D CANVENT program it was found necessary to eliminate three ventilation constructions. 
By eliminating the ventilation constructions, the air flow through the abatement with undermined coal bank and implicitly the safety and health conditions has been considerably improved.

The results obtained were optimization of the ventilation network, the fresh air flow that goes into the longwall with undermined coal bed was optimized.

Thus, a normal level of oxygen is ensured in the longwall with undermined coal bed, and by increasing the air flow, an appropriate dilution of the gases emitted from the coal layer is achieved.

\section{Conclusions}

Following the monitoring of the longwall with undermined coal bed located in panel 5 , layer 3, block IV, a relatively normal situation was identified, but there were some exceptions when higher $\mathrm{CO}$ and $\mathrm{CO}_{2}$ values were detected and the values of fire indices Graham and Breath were higher.

By using the specialized 3D CANVENT program, with which the ventilation network was optimized, the fresh air flow that goes into the longwall with undermined coal bed was optimized.

Thus, a normal level of oxygen is ensured within the longwall with undermined coal bed, and by increasing the air flow, an appropriate dilution of the gases emitted from the coal layer is achieved.

In addition to preventing the phenomenon of self-heating and avoiding endogenous fire, it was recommended to apply the softening technology with the addition of chemical substances and the application of the aerosol technology in intensive mode at longwall level.

Thus, with the help of the specialized 3D Canvent program and based on the on-site measurements performed at that time, the safety level within the longwall with undermined coal bed analysed could be increased.

\section{References}

1. C. Teodorescu, Z. Gontean, I. Neag, Mining ventilation, (in Romanian), (Technical publishing house, Bucharest, Romania, 1980)

2. R. D. Lama, Proceedings of the $4^{\text {th }}$ international Mine Ventilation Congress, Brisbane, Australia, (1988).

3. A. M. Patterson, Practitioner's Data Book, (M.V.S. of South Africa, 1992).

4. R. Baltaretu, C. Teodorescu, Ventilation and safety in mines, (in Romanian), (Didactical and Pedagogical Publishing House, Bucharest, Romania, 1971).

5. S. Covaci, Underground mining, (in Romanian), (Didactical and Pedagogical Publishing House, Bucharest, Romania, 1983)

6. 3D CANVENT - User Manual. 